\title{
THE FORECLOSURE OF VESSEL MORTGAGES IN ADMIRALTY.
}

The Supreme Court has long sanctioned substantive legislation by Congress designed to bring our maritime law abreast of the Congressional idea of the needs of maritime commerce. Formerly the source of Congressional authority was held to be derived from the power to regulate interstate and foreign commerce. ${ }^{1}$ This is the basis of decisions sustaining the Vessel Sales and Mortgage Recording Act of $1850,{ }^{2}$ and the Seamen's Acts prohibitions upon the payment of wages in advance, and of the early cases arising under the Limited Liability Act of $185{ }^{1 .}{ }^{4}$ In later cases, however, the court turned to the doctrine of a Congressional power to legislate upon maritime matters within admiralty jurisdiction implied from the Constitutional grant of that jurisdiction to the federal courts and the "necessary and proper" clause. 5 Thus the more recent cases under the Limited Liability Act of $185^{1},{ }^{6}$ the Limited Liability

${ }^{1}$ The Lottawanna (1874), 2I Wall. 558, 577 .

${ }^{2}$ White's Bank v. Smith (1868), 7 Wall. 646, 655-6; Aldrich v. Aetna

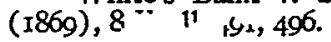

${ }^{2}$ Pat. son v. Bark Eudora (1903), I90 U. S. 169, 176. Cf. Strathearn S. S. Co. v. Lillon (1920), 252 U. S. 348.

Providence \& New York S. S. Co. v. Hill (I883), I09 U. S. 578, 589; In re Vessel Owners' Towing Co. (D. C., 1886), 26 Fed. 169, 170.

s "The judicial Power shall extend . $\therefore$ to all cases of admiralty and maritime Jurisdiction. . "-Const. Art. III, Sec. 2.

"The Congress shall have Power . - to make all Laws which shall be necessary and proper for carrying into Execution the foregoing Powers, and all other Powers vested by this Constitution in the Government of the United States, or in any Department or Officer thereof."-Const., Art. 1, Sec. 8. Southern Pacific Co. v. Jensen (19I7), 244 U. S. 205, 214-15.

"The Constitution itself adopted and established, as a part of the laws of the United States, approved rules of the general maritime law, and empowered Congress to legislate in respect of them and other matters within the admiralty and maritime jurisdiction. . . To preserve adequate harmony and appropriate uniform rules relating to maritime matters and bring them within control of the Federal Government was the fundamental purpose; and to such definite end Congress was empowered to legislate within that sphere."-Knickerbocker Ice Co. v. Stewart (I920), 253 U. S. 149.

${ }^{6}$ Butler v. Boston \& Savannah S. S. Co. (I888), I30 U. S. 527, 555; The Garden City (D. C., I886), 26 Fed. 766, 768-9; In re Long Island, etc., Tránsportation Co. (D. C., 188I), 5 Fed. 599, 6I5-8. See Lord v. Steamship Co. (I880), I02 U. S. 54I, 545 . 
Act of $1884,{ }^{7}$ and the navigation laws, ${ }^{8}$ present subjects recognized as within the admiralty jurisdiction. and so are rested upon this implied power.

Among the s sbstantive provisions of the Ship Mortgage Act, I920, ${ }^{9}$ is the establishment of a preferred status for a vessel mortgage lien in the distribution of the proceeds upon foreclosure of the mortgage, as against repairmen's, supplymen's, towage, and all other maritime liens, except maritime liens arising prior to the mortgage or. from tort, and liens for salvage, general average, or wages of crew and stevedores. ${ }^{10}$ The mortgagee, by the standard marine insurance policy, together with a protection and indemnity clause, can protect himself against practically all of these exceptions but the lien for wages. Inasmuch as the Congressional power to legislate implied from the Constitutional grant of admiralty jurisdiction is limited to subject matters within such jurisdiction, the constitutionality of the preferred status provision, if founded upon this source of power, as stated by the Congress, ${ }^{11}$ instead of upon the commerce power, depends upon the answer to the question whether the foreclosure of a vessel mortgage is a subject matter within the admiralty jurisdiction since the enactment of the Ship Mortgage Act, I920. The question whether the foreclosure of a vessel mortgage may by Congressional legislation be placed within the admiralty jurisdiction is als.' ' 'ented directly by the act, for it requires that the foreclosure proceedings be brought in the federal courts in admiralty, ${ }^{12}$ instead of, as heretofore, in equity in the state courts or, in case of diversity of citizenship, in the federal courts.

The practical necessity for foreclosure in the federal courts

'In re Garnett (1890), I4I U. S. I, I2.

'U. S. v. Burlington \& Henderson County Ferry Co. (D. C., I884), 21 Fed. 33I, 339. Cf., contra, The City of Salem (D. C., I889), 37 Fed. 846.

- Public-No. 26r-66th Congress, Sec. 30.

${ }^{10}$ The Ship Mortgage Act, I920, Subsec. M. For the economic considerations involved in the preferring of vessel mortgage liens, see 20 Columbia $I$. Rev. 78g. For the procedure by which the preferred status of the vessel mortgage lien is preserved upon foreclosure of the mortgage, and upon the libel of a mortgaged vessel for the enforcement of a preferred mortgage lien, see Report of the Special Committee on Noteworthy Changes in Statute Law, I92I, American Bar Association Committee Reports, 105, 106.

${ }^{11}$ Reps. Nos. 1093 and I102, H. R. 66th Cong., p. 34.

${ }^{12}$ Ship Mortgage Act, 1920, Subsec. $\mathrm{K}$. 
and in admiralty arises from the need for a simple, comparatively expeditious, and uniform proceeding, not obtainable under the varied mortgage laws of the many maritime states, and the diverse interpretations of their courts, ${ }^{13}$ and for a pr'xeeding in which all maritime liens are extinguished; for if, as in the equity practice, the vessel is sold subject to the maritime liens, though they arise subsequent to the creation of the mortgage, ${ }^{14}$ the mortgagee suffers a proportionate reduction in the amount which the vessel will bring at the foreclosure sale and thus in actual effect is subordinated to such liens. The combination of advantages (believed necessary by the Congress, is found only in the federal courts in admiralty. ${ }^{15}$ Previous to the Ship Mortgage Act, 1920, how-

13،. . . with a speedy and uniform procedure of foreclosure in the federal courts, the security of a mortgage wiil be greatly enhanced by the provisions of the proposed act over its status under existing law."-Brief by Ira A. Campbell, Esq., Hearings, Committee on Commerce, Senate, "Establishment of an American Merchant Marine," 66th Cong., p. 976; Hearings, Committee on Merchant Marine and Fisheries, House of Representatives, "Recording of Mortgages on Vessels, etc." 66th Cong., Pt. V, p. 58.

${ }^{13}$ See The Bud III (D. C., I9I8), 250 Fed. 9I8; Moran v. Sturges (1894), 154 U. S. 256, 277; Woodward v. Dilworth (C. C., 1896), 75 Fed. 415; The Lil: lie (D. C., I889), 40 Fed. 367 ; The N. W. Thomas (C. C., I857), I8 Fed. Cas. No. I0,385; The Powell (C. C., I870), I6 Fed. Cas. No. 9324; The John Richards (C. C., 1856), I3 Fed. Cas. No. 7361; Hill v. The Golden Gate (C. C., I857), I2 Fed. Cas. No. 649I; Harris v. The Henrietta (D. C., 1856), in Fed. Cas. No. 6rzI.

${ }^{25}$ An earlier draft of the Ship Mortgage Act, I920, prepared by Ira A. Campbell, Esq., former admiralty counsel of the United States Shipping Board, and adopted by the Senate and found in Sec. 32 of $H$. $R$. 10,378, 66th Cong., as passed by the Senate, attempted, in the manner of the "libel of condemnation" in the Food and Drugs Act (34 Stat. 771, Sec. Io), and the Confiscation Act of 1862 (I2 Stat. 59I, Secs. 7 and 8), to authorize a proceeding in equity, but simulating admiralty by making use of the admiralty procedure and giving title upon the court sale good against the world, all claims, including maritime liens, against the vessel being extinguished. The objections which presumably forced the adoption in conference committee of the direct and admittedly preferable (if constitutional) admiralty proceeding substitute offered by the House conferees and finally enacted, may be enumerated as follows:

I. Few foreclosure cases could reach the federal courts, for if the federal court's jurisdiction in equity is based on diversity of citizenship, the banking interest and the vessel owner must be residents of different states, and if the equity proceeding were in simulation of admiralty in rem with the vessel as the defendant, it is doubtful if a vessel of the United States, $i$. e., any documented vessel, could be personified as a citizen of any state. An analogous situation is presented by a federal corporation, which has been held not to be a citizen of any state. Bankers' Trust Co. v. Texas Pacific Co. (I915), 24I U. S. 295, 309. And if the federal court's jurisdiction is based on the only other Constitutional source, "a case in law or equity arising under a law of the United States," there is a serious doubt as to whether the right to foreclosure, originating as it does from the private mortgage contract and not from any law of the United States, once its constitutionality had been estab- 
ever, it was held in the John Jay ${ }^{16}$ and subsequent cases that a vessel mortgage was not a maritime lien or contract under the "general maritime law," and in the absence of Congressional legislation upon the subject could not be foreclosed in admiralty, although upon the libel of a mortgaged vessel to enforce a maritime lien, the mortgagee might intervene as a claimant or petitioner and have his claim satisfied from any balance of the proceeds of the libel sale after paying off all maritime liens. ${ }^{17}$ The problem for the courts is: "Are the provisions of the Ship Mortgage Act; I920, altering this situation, constitutional ?"

The arguments in favor of the constitutionality of the foreclosure in the federal district courts in admiralty provisions are seemingly as follows: The grant of admiralty jurisdiction to the federal district courts is not self-executing. ${ }^{18}$ Not only must the Constitution give the court capacity to receive jurisdictional

lished and doubtful points of construction settled, would present a case "arising under a law of the United States." See Cohens v. Virginia (182r), 6 Wheat. 265; Spencer v. Duplan Silk Co. (I903), I9I U. S. 526, 530; Schulteis v. McDougal (1912), 225 U. S. 56r, 569; Nelson v. So. Ry. Co. (C. C. A., I909), 172 Fed. 478; Leggett v. Great Northern Ry. Co. (C. C. A., I910), I80 Fed. 3I4; Hubbard v. Chicago, M. \& St. P. Ry. Co. (C. C. A., 1910), 176 Fed. 944; Storm Lake Tub \& Tank Factory v. St. Louis Ry. Co. (D. C., Igr3), 209 Fed. 895; Myrtle v. Nevada, etc., Ry. Co. (C. C., I905), I37 Fed. I93; McGoon v. Northern Pacific R. R. Co. (D. C., I913), 204 Fed. 998; and statement of Robert M. Hughes, Esq., Hearings, Committee on Merchant Marine and Fisheries, House of Representatives, "Recording of Mortgages on Vessels, etc." 66th Cong., Pt. III, p. \&o. Cf., contra, Wells, Fargo \& Co. v. Cuneoi (D. C., 1917), 241 Fed. 726 and 74I.

2. Jurisdiction of a matter within the admiralty grant of the Constitution, as the termination of maritime liens, may not be given to a court other than admiralty, either federal or state, for no Act of Congress can narrow the grant of admiralty jurisdiction to the federal courts in admiralty or deprive them of any portion of it. The Lottawanna [1874], 2I Wall. 558, 576; Moran v. Sturges [1894], I54 U. S. 256, 280-2. The jurisdiction of the federal courts in admiralty is exclusive.

3. Titles derived from equitable sales have not the international validity accorded admiralty titles. This would be especially true as against the claim of a maritime lienor, a citizen of the country, of the foreign forum who had no personal notice, but merely the customary admiralty citation, of the sale in equity in the United States court which resulted in the termination of his lien.

${ }^{18}$ Bogart v. The Steamboat John Jay (1854), i7 How. 399; The J. E. Rumbell (I892), I48 U. S. I, 15. Cf. The Lottawanna (I873), 20 Wall. 20I, 221.

${ }^{17}$ Schuschardt v. Babbige (1857), 19 How. 239; The Emily Souder (1873), I7 Wall. 666, 672; The Valencia (I897), I67 U. S. 268; The Glide (I897), -I67 U. S. 623 . C $f$. The Lottawanna (1873), 20 Wall. 201, 221.

${ }^{18}$ U. S. v. Bevans (I8I8), 3 Wheat. 336,387 ; U. S. v. Hudson (1812), 7 Cranch. 33; Mayor v. Cooper (1867), 6 Wall. 247, 252; Kentucky v. Powers (1905), zoI U. S. I, 24. Contra, The Wave (183I), 29 Fed. Cas. No. 17,297. 
powers, but an Act of Congress must supply them. ${ }^{10}$ The Congress may distribute all the jurisdiction made available to the court by the Constitutional grant, or to such extent as it pleases, fall short of complete distribution. The language of the Constitution granting admiralty jurisdiction not only established jurisdiction available for distribution, but also adopted the rules of the "general maritime law" as determined by our courts, ${ }^{20} i$. e., an eclectic combination of the law in vogue in the continental codes, England, and the colonial and state courts about the time of the adoption of the Constitution in $1789 .{ }^{21}$ Therefore cases arising under the "general maritime law" as recognized by our courts, are cases within the admiralty jurisdiction. Were these the only cases within such jurisdiction, however, the Constitution, while permitting the growth of the substantive policies of maritime law, would, as to the jurisdiction, have adopted the status quo of I789 and denied to admiralty the power to administer cases arising under legislation upon subjects not within the "general maritime law." Today, even England has fallen in line with all the great maritime countries and made the foreclosure of the vessel mortgage a matter of admiralty jurisdiction. ${ }^{22}$ It is therefore urged that the grant of admiralty jurisdiction made available for distribution to the federal courts not only cases arising under the "general maritime law," but also cases upon such other maritime subjects not within the "general maritime law," but properly related to maritime commerce, as Congress may enact legislation upon from time to time. Declarations that the admiralty jurisdiction is not confined to cases arising under the "general maritime law," and that in determining the extent of admiralty jurisdiction the courts must look also to Congressional legislation, are found in many decisions. ${ }^{23}$ The Judiciary Act of $1789,{ }^{24}$ as re-

${ }^{19}$ Mayor v. Cooper (1867), 6 Wall. 247, 252.

${ }^{20}$ Knickerbocker Ice Co. v. Stewart, see quotation, supra, footnote 5; Schuede v. Zenith S. S. Co. (D. C., I914), 216 Fed. 566, 567. Cf. The Lottawanna (1874), $2 \mathrm{I}$ Wall. $558,574$.

${ }^{21}$ The Lottawanna (1874), 2I Wall. 558, 574, 576; Ex parte Easton (I877), 95 U. S. $68,70,76$; Butler v. Boston S. S. Co. (I888), 130 U. S. $527,556$.

${ }^{22} 3$ \& 4 Vict., Chap. 65, Sec. 3 ; 24 Vict., Chap. Io, Sec. II; Mayer, Admiralty Law and Practice (I9I6), pp. 70-I.

${ }^{23}$ See Knickerbocker Ice Co. v. Stewart, supra, footnote 5; Bogart v. 
enacted to date, ${ }^{25}$ in distributing to the federal courts in the precise language of the Constitution, jurisdiction over "all cases of admiralty and maritime jurisdiction," may then be conceived of either as distributing to the federal courts jurisdiction to administer cases arising under the "general maritime law" only (which comprised the sole body of rules in force in respect to maritime commerce in 1789 ), while jurisdiction of other cases must be distributed by special enactment, as in subsection $\mathrm{K}$ of the Ship Mortgage Act, 1920 ; or else as distributing jurisdiction of all admiralty cases ${ }^{26}$ as fast as the necessary substantive legislation makes them available. Neither proposition necessitates overruling the John Jay. ${ }^{27}$ The Limited Liability Act of $1884,{ }^{28}$ in authorizing proceedings in admiralty to limit liability for damage arising from non-maritime torts, $i$. $e$, torts not within the "general maritime law," affords a direct precedent for the Ship Mortgage Act, I920, and its constitutionality has been sustained. ${ }^{29}$

If cases other than those arising under the rules of the "gen-

Steamship John Jay (1854), I7 How. 394, 402-3; The Roanoke (I903), I89 U. S. 185 , 198; Ex parte Easton (1877), 95 U. S. 68, 70; Waring v. Clarke (1847), 5 How. 44I, 457.

"I Stat. 76,89 .

${ }^{25} 40$ Stat. 395 .

${ }^{2}$ Cf. American Steamboat Co. v. Chase (1872), I6 Wall. 522; Insurance Co. v. Dunham (I870), II Wall. I, 23.

${ }^{27}$ Supra, footnote 16 . It is also possible to sustain the foreclosure provisions of the Ship Mortgage Act, 1920, by overruling The John Jay and holding that the foreclosure of a vessel mortgage is a matter within the "general maritime law." A precedent for such action is afforded by The Propeller Genessee Chief v. Fitzhugh (1851), 33 U. S. 443, in which, when confronted by Congressional legislation, the court reversed The Steamboat Thomas Jefferson (1828), 23 U. S. 428 , and held, despite that case and subsequent decisions following it, that under the "general maritime law" navigable waters other than those within the ebb and flow of the tide, as the Great Lakes and Mississippi River, were within admiralty jurisdiction. See 20 Columbia L. Rev., 788,790 .

${ }^{25} 23$ Stat. 53.

${ }^{29}$ Richardson vi Harmon (I9II), 222 U. S. 96, 106; The Steam Dredge No. 6 (D. C., 1915), 222 Fed. 576, 578, affirmed: The Number 6 (C. C. A. I917), 241 Fed. 69,71 . Compare the decision upon a case similar as to facts, but arising previous to the Congressional Act of 1884 (23 Stat. 53), which holds that the doctrine of limited liability would not extend to a "non-maritime". tort, i. $e$., a tort not within the "general maritime law." Ex parte Phenix Insurance Co. (1886), II8 U. S. 610. Norwich Co. v. Wright (187I), I3 Wall. 104, 123-4, holds that proceedings to limit liability shall be brought in the federal courts in admiralty.

The argument presented above is also advanced in the Report of Special Committee on Noteworthy Changes in Statute Law, 1921, supra, footnote to. 
eral maritime law" are within the jurisdiction available for distribution to the federal courts, what are the limits by which it can be determined whether Congressional legislation is distributing jurisdiction of such a case or enacting substantive law under its implied power to legislate in respect thereto? It is, of course, the duty of the courts to declare unconstitutional legislation which distributes jurisdiction to the federal courts in admiralty over cases not within these limits, for, as commonly phrased, the Congress may not by legislation broaden or narrow the Constitutional grant of admiralty jurisdiction. ${ }^{30}$ It is in this sense that the limits of admiralty jurisdiction are a judicial matter. The limits of any grant of power by the Constitution are to be determined by the courts and are not a legislative matter or subject to alteration by statute. But the ancient doctrine does not concern the power of Congress to distribute jurisdiction of cases in respect to matters within the Constitutional grant. ${ }^{31}$ Obviously the

${ }^{30}$ The Propeller Genessee Chief v. Fitzhugh (I85I), I2 How. 443, 452; The Steamer St. Lawrence (186r), I Black 522, 527; The Lottawanna (1874), 2I Wall. 558, 575-6; The Blackheath (1904), I95 U. S. 36I, 365, 369; Butler v. Boston S. S. Co. (1888), 130 U. S. 527, 556.

${ }^{31}$ See a common misapplication of the doctrine in the Report of the Committee on Maritime Law, I920, 6 American Bar Assn. Jour., 4I6.

The limits of that portion of admiralty jurisdiction comprising the "general maritime law," i. e., what cases in the absence of Congressional legislation, constitute cases in admiralty due to the fact that the Constitutional grant of admiralty jurisdiction includes, among others, all cases arising under the rules of the "general maritime law" is, of course, a judicial question to the extent that judges are to determine what rules are, except as modified or amended by Acts of Congress.

The language employed to define contracts within "the general maritime law," namely, that the contracts have reference to "maritime transactions," or "commerce upon navigable waters" [Peoples Ferry Co. v. Beers (1857), 20 How. 393, 401 ; Philadelphia, Washington \& Baltimore $R$. R. Co. v. Philadelphia, etc., Steamboat Co. (1859), 23 How. 209, 215; Insurance Co. v. Dunham (I870), Ir Wall. I, 26; The Eclipse (I890), I35 U. S. 599, 608; U. S. v. Burlington \& Henderson Co. Ferry Co. (D. C., I884), 2I Fed. 33I, 336; The Ada (C. C. A., 1918), 250 Fed. 194, 197], would be sufficiently broad to include the vessel mortgages were it not that following the old English decisions, the foreclosure of a vessel mortgage was nevertheless held in the John Jay and subsequent cases not to be within the "general maritime law."

${ }^{33}$ As an extreme case, a mortgage of real estate could not constitutionally be brought within admiralty jurisdiction. The Ship Mortgage Act, 1920, confined preferred mortgages to vessel property only, excluding a blanket mortgage including property other than vessels, unless the mortgage provides for the separate discharge of the non-vessel property, $i$. $e$., is really two mortgages, of which only the mortgage relating solely to vessels is placed within the admiralty jurisdiction. See Ship Mortgage Act, 1920, Subd. (e), Subsec. D, and Subd. (b), Subsec. N. 
limits to the Constitutional grant of admiralty jurisdiction are broader than those of the "general maritime law,"32 yet it is equally obvious that the subject matter must bear some proper relationship to maritime commerce. ${ }^{33}$ What this relationship is, will doubtless be developed slowly as the cases arise, just as the court has done in the decisions defining what constitutes interstate commerce or due process of law. ${ }^{34}$

\section{Washington, D. C.}

Clarence A. Miller.

"The demands of commerce require that liberal interpretation be applied in determining the extent of admiralty jurisdiction. The Blackheath (I904), I95 U. S. 36r, 369, per Brown, J.

"But a very little history is sufficient to justify the conclusion that the Constitution does not prohibit what convenience and reason demand."-Ibid, per Holmes, J. See The Underwriter (D. C., I902), II9 Fed. 713, 744, and Borgnis v. Falk (IgII), I47 Wis. $327,348-50$. 